\title{
Segunda ola del COVID-19: Otra vez desarmados
}

\section{Second wave of COVID-19: Again unarmed}

\author{
Aland Bisso-Andradel
}

La pandemia de Influenza de 1918 dejó el mensaje que una segunda ola es peor que la primera. En la actual pandemia no podría ser la excepción. Los políticos y el ciudadano común, en esencia, siguen siendo los mismos. Se sacrifica salud por economía; seguridad por diversión. Los gobiernos anteponen sus intereses partidarios y populistas. Las medidas son efímeras, tibias, apenas un placebo para la opinión pública. Los discursos mediáticos abundan, todos son "expertos" en una enfermedad nueva que acaba de cumplir un año. Hasta el menos pensado ansía la figuración. Las redes sociales explosionan. Apenas uno de cada 50 mensajes tiene algún valor rescatable. Todos reenvían. Ni siquiera se dan el tiempo para leer el texto completo, se asume que "debe ser interesante" y se reenvía. No hay actitud crítica. Todo vale. La metodología científica y la medicina basada en evidencia son apenas reminiscencias caducas frente al caos. Los congresistas dedican jornadas enteras para discutir el valor del dióxido de cloro, un alcalde reparte miles de frascos de ivermectina como si fuera loción mágica para los calvos; y, la televisión se presta a la feria: "la ivermectina es mejor que la vacuna"; "el dióxido de cloro es la solución". La receta popular sigue creciendo: azitromicina, hidroxicloroquina, ivermectina, dióxido de cloro, warfarina, aspirina, paracetamol, corticoides, bicarbonato, zinc, vitamina $\mathrm{D}$, vitamina $\mathrm{C}$, miel, jengibre, té verde y limón. Misma pócima de la Edad Media: "Junte todo, haga un licuado y tómese una cucharadita cada 4 horas". Entrevistas y vídeos con médicos cargados de títulos y medallas refrendan las fórmulas secretas. Mientras tanto, mascarillas, distanciamiento y buena higiene de manos, pasan a segundo plano. "La OMS miente", dijo Trump y el primer ministro inglés siguió el mal ejemplo. Hordas enteras marcharon en contra de las medidas de prevención en los Estados Unidos, Reino Unido, Francia y Alemania, y ahora todos ellos están dentro de los 10 países con mayor cantidad de casos y de muertes. El Perú no podía ser diferente, acá las hordas no salieron a pelear contra la restricción, salieron a desbancar al cuestionado presidente

I Médico internista. Past presidente de la SPMI.
Bisso-Andrade A. Segunda ola del COVID- 19: Otra vez desarmados. Rev Soc Peru Med Interna. 202I;34(I): 5-6.

https://doi.org/I0.36393/spmi.v34il.576

Merino, a bloquear carreteras so pretexto de una ley agraria nefasta, a comprar regalitos en Mesa Redonda y calzones amarillos para el 31 de diciembre. Los chichódromos y discotecas clandestinas volvieron a su estado natural, además de bodas, bautizos, quinceañeros y cambios de aro, y aparecieron alcaldes deslenguados celebrando en fiestas de Año Nuevo. Acá es más fácil multar a un bañista solitario en una playa sin un alma en cinco kilómetros a la redonda que multar ambulantes gritando a garganta pelada y con la mascarilla de corbata. El populorum venció a la autoridad. "Tengo que trabajar", contesta el informal.

Los medios de prensa son un mosaico variopinto que manipula la información a regalada gana. De un día para otro, médicos y policías pasan de héroes a villanos. Se confunde vocación de servicio con esclavitud. Si el sacrificio no es reconocido ni bien remunerado, es explotación. ¿El irresponsable que ignora el toque de queda y sale a embriagarse con sus amigos tiene los mismos derechos que el ciudadano que cumple las órdenes de restricción? ¿El funcionario público que hace teletrabajo burocrático desde la comodidad de su casa tiene los mismos derechos que el personal de salud que atiende en los hospitales en forma presencial? ¿Por qué, después de un año de pandemia, los trabajadores de la salud siguen reclamando sueldos, beneficios y equipos de bioseguridad? ¿Conocen algún congresista o ministro que amenace con hacer huelga por falta de pago de incentivos, bonos o porque solo recibió 300 soles de gratificación? ¿Qué esperamos después de la segunda ola? Tal vez más de lo mismo. Tal vez se pudo evitar o amenguar su devastación si se tomaban otras medidas en fecha más temprana. Las medidas de restricción que dio el gobierno el 13 de enero debieron darse a inicios de diciembre. Dejar el comercio ambulatorio a su libre albedrío fue un error. Tratar de reactivar la economía a cambio del colapso de hospitales y mayor mortalidad, jamás puede 
ser un buen negocio. Sin salud no hay economía, no hay trabajo, no hay nada. Si la pandemia persiste incontenible las consecuencias serán peores, no solo las restricciones serán más duras, aumentarán la mortalidad y el desempleo, bajará más el PBI y la lista de médicos y policías muertos será mayor. Ese es el precio de "reactivar" la economía sin los frenos correspondientes en medio de una sociedad irresolutamente irresponsable que raya en una estupidez ya cotidiana y sin remedio.

Ni la ivermectina ni la mejor vacuna van a contener al virus si no se mantienen las únicas tres medidas de prevención hartamente consabidas: mascarilla, distancia y lavado de manos. El virus seguirá sus leyes naturales de sobrevivencia. El mayor favor que le pueden hacer es pretender la "inmunidad de rebaño". La inmunidad tiene que surgir de la vacunación masiva, y si le suman mascarilla, distancia e higiene, el virus perderá fuerza, su carga infectante caerá y se diluirá como cualquier otro virus común. Pero la vacuna aún no llega. La gestión peruana se diluyó entre la cancillería, el "Comando COVID" y el Ministerio de Salud; así, mientras que el congreso se preocupaba más por vacar al ex presidente Vizcarra, nunca terminaron de sacar la ley que aprobaría una compra millonaria. Ahora tendremos una vacuna que vale siete veces más que la de Pfizer y quince veces más que la de AstraZeneca. Es probable que, de haberse dado fuertes medidas de restricción en el momento apropiado y se iniciaba la vacunación en diciembre, como ya viene ocurriendo en otros países, esta segunda ola sería apenas un brote controlable con menos víctimas que lamentar. Pero en un país como el nuestro, nunca se sabe.

Lima, 14 de enero del 2021.

\section{NOTA DEL EDITOR}

Al cierre de la edición, el pasado 7 de febrero arribó a Lima el primer lote de 300000 dosis de vacunas Sinopharm contra el COVID-I9. 